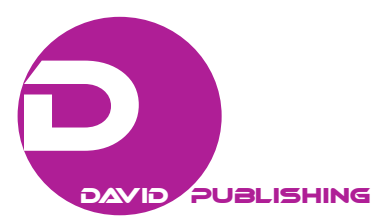

\title{
Empowerment, Organizational Commitment, Organization Citizenship Behavior and Firm Performance
}

\author{
Anne Kariuki, Kellen Kiambati \\ Karatina University, Karatina, Kenya
}

\begin{abstract}
The broad objective of this study was to establish the mediating and moderating effect of employee commitment and organizational citizenship behaviour on the relationship between empowerment and firm performance. The review of literature provided conceptual and empirical gaps that formed the basis of the conceptual hypotheses. The study adopted a quantitative approach and a survey that targeted a manufacturing firm in Kenya was utilized. A survey questionnaire was the tool of data collection and was distributed to the 96 non-managerial employees of a manufacturing firm. Out of the 96 questionnaires issued randomly, 86 were returned, indicating a $91.6 \%$ response rate. The reliability test showed that study dimensions were reliable. Inferential statistics was used to analyse data. Results showed that employee empowerment had a positive and significant influence on organizational performance; organizational commitment mediated the relationship between employee empowerment and organization performance; and OCB did not have a moderating effect.
\end{abstract}

Keywords: employee empowerment, organizational commitment, organizational citizen behaviour (OCB), job satisfaction, productivity and organizational performance

\section{Introduction}

The concept of employee empowerment has generated great interest among academicians and practitioners owing to its link to above average performance. Nevertheless, despite widespread belief held by academicians and practitioners that empowerment has a significant influence on firm performance, empirical evidence from management research supporting the proposition has presented inconsistent findings. The inconsistencies nature of the results motivated some scholars to investigate other possible explanations for divergence in findings. There are various reasons that have been advanced including methodological flaws, confusion, and inconsistencies in conceptualization of the concept of empowerment. The majority of the studies that have investigated the existence of a relationship between empowerment and firm performance have assumed the existetence of a direct relationship. This assumption has come under question as Boxall and Macky (2009) pointed out the omission of organizational commitment. This was earlier supported by Meyer, Stanley, Herscovitch, and Topolnyski (2002) who suggested that employee commitment is a critical determinant of employee empowerment. In addition, Guest (1997) argued that individual perception of Human Resource Management (HRM) systems is most related to individual and attitudinal behavioral outcomes such as

Anne Kariuki, Dr., Ph.D. in Business Administration, Karatina University, Karatina, Kenya.

Kellen Kiambati, Dr., Ph.D. in Business Administration, Karatina University, Karatina, Kenya.

Correspondence concerning this article should be addressed to Anne Kariuki, Karatina University, P.O. Box 1957-10101 Karatina, Kenya. 
organizational commitment and job satisfaction. This study is a response to studies that argue the relationship between employee empowerment and performance is not as linear as depicted in literature. A large proportion of unexplained variation and conflicting results can be explained by other factors such as organizational commitment and Organization Citizenship Behavior (OCB).

A frequent further limitation is that previous studies have mainly focused on analyzing the effect of empowerment on organizational level outcomes such as productivity, organization performance by focusing on managerial employees. Kariuki and Murimi (2015) recently argued that the concept should be measured from an employee's perspective. More recently, researchers have questioned the use of managerial employees in human resource management research. They have called for more research which examines individual perception of employee empowerment. Hence rather than relating to employee empowerment practices as rated by managers, this study examines employee perception of empowerment.

This paper addresses an introduction showing the importance of this topic and the problem in the area of study, literature review against which this paper is anchored, methodology adopted, data analysis, discussion and conclusion.

\section{Literature Review}

\section{Theoretical Framework and Research Hypotheses}

In studying the underlying process we draw on Blau's (1964) Social Exchange Theory (SET). Blau suggested that individuals are drawn to participate and invest in rewarding relationship after which they become bound to either benefit or favor their partners in exchange. Employee empowerment if implemented effectively creates obligatory reciprocation in their exchange relationship.

\section{Employee Empowerment and Organizational Performance}

Wood (1999) argues that empowerment is a departure from Tayloristic style of management that emphasizes employee control through narrow and tightly specified jobs supported by task-focused selection, training and payment system to an approach emphasizing employee involvement in training and development, immediate need and good communication, up and down the organization, self-managing teams and participation eliciting commitment towards organizational goals (Cooper \& Roberston, 2004). Foresster (2000) defined empowerment as freedom or ability to make decisions and commitments. Although employee empowerments vary across studies, a commonality across studies is that it is a multi-dimensional concept that has positive and negative effect on organizational outcomes.

Kanter (1992)'s structural empowerment represents employee access to organizational empowerment structures that enhances the work effectiveness. Rather than conferring power on staff (passive approach), leaders socially engage with staff encouraging them to self-manage and self-lead (an active approach) (Pearce $\&$ Sims, 2002). On the other hand, psychological empowerment represents employee perception of being empowered at work and can be traced to the work of Conger and Kanungo (1990). They incorporated four commonly agreed practices meaning, impact, self-determination, and competence (Conger \& Kanungo, 1988; Spreitzer, 1995; 2007). Given these commonalities we constructed a list of four practices. Menon (2001) suggested that empowerment involves traditional decision-making making authority down the organization hierarchy. Quinn and Spreitzer (1997) found that psychological empowerment increases employee sense of personal control which in turn results in positive managerial and organizational outcomes. 
The researches of Lashley (1995), Bowen and Lawler (1992), and Kazlauskaite, Buciuniene, and Turauskas (2012) suggest that empowerment leads to motivated and responsive staff, lower labour turnover and costs, increased productivity, higher service quality, bigger profits, higher customer loyalty, better use of employee knowledge and skills. Similarly, Menon (1995) found that greater empowerment led to increased internal work motivation, heightened job satisfaction, job involvement within and beyond the defined job responsibilities and low job-related stress. Speritzer (1995a) in their study using a sample of 393 managers found that all four sub-scales were positively related to antecedents of access of information and three of the four except meaning were associated with self-esteem. The study did not test for mediation effect of organizational commitment. Furthermore, the work was based on a single sample of mangers leaving generalizability unknown and self-report from mangers can be biased. Spreitzer (1996) surveyed 393 mid-level administrators of Fortune 500 corporations and found that empowered employees have little ambiguity about their role in the organization. From these findings, he came to the conclusion that leaders in organizations that are empowered have an unlimited control scope, leading to greater autonomy.

Liden, Wayne, and Sparrow (2001) who studied on 337 lower level service company employees found that psychological empowerment mediate relationship between job characteristics and outcomes (work satisfaction, organizational commitment, and job performance). In their study, role ambiguity completely accounted for relationship between job characteristics and commitment. Likewise, Yang and Choi (2009) conducted a survey of 176 US municipal government employees using regression analysis. The study regressed the dependent variable team performance, on the four independent variables: autonomy, responsibility, information, and creativity, which are factors of empowerment. Their findings from the regression analysis provided empirical evidence that the independent variables each have positive and significant effects on team performance. Ibua (2014) reported that employee empowerment (training and development, autonomy, involvement in decision making, access to information, management support) had a positive and significant influence on financial (revenue growth) and non-financial performance of public universities in Kenya. Although the results were significant, the results showed a very weak model between employee empowerment (3.8\%) implying that there could be other factors that account for the variation between employee empowerment and performance.

It is evident from the foregoing discussion that there is evidence of relationship between employee empowerment and performance. However, there seems to be some weakness in the studies which should be addressed. We propose that:

$\mathrm{H}_{1}$ : Employee empowerment has a positive influence on organizational performance.

\section{Employee Empowerment, Organizational Commitment and Performance}

Kazlauskaite et al. (2012) suggest that employee empowerment is related to performance outcomes such as employee attitudes and behaviour such as trust, job satisfaction, commitment, employee turnover, and OCB. Seibert et al. (2011) point that empowerment has both positive (job satisfaction, organizational commitment and task and contextual performance) and negative outcomes (employee strain and turnover intentions). Fernandez and Moldogaziev (2011) established that employee empowerment is positively related to job satisfaction and organizational commitment.

Guest (1997) argues that individual perception of human resource management systems are most related to individual and attitudinal behavioural outcomes such as organizational commitment and job satisfaction. 
Luthans (2007) defines employee commitment as a mindset reflecting employee faithfulness to their organization and it is a continuing chain by which organization's members utter their concern regarding the organization and its development. Tansky and Cohen (2001) define commitment as the strength of an individual identification and involvement. Commitment is feelings towards the organization which directly influences performance. Allen and Meyer (1990) in their study presented three types of commitment: (1) affective commitment which refers to employees emotional attachment to, identification with and involvement in the organization, (2) continuance commitment, (3) normative commitment as obligation to stay from a moral point of view independent of their gains from the organization, that is desire to remain in the organization.

Meyer et al. (2002) found a strong correlation between affective commitment and outcome variables on turnover and withdrawal cognition, absenteeism job performance, OCB, stress and work-family conflicts. Commitment is assumed to be positively related to behaviours that are beneficial to the organization. Drawing on social exchange theory, empowered employees are willing to reciprocate with high levels of commitment given that they believe in their work and themselves. Psychological empowerment contributes to as sense of committed behaviours to the organization through a process of reciprocation. Liden et al. (2001) further state that affective commitment is positively related to behaviours that are beneficial to the organization such as performance, attendance, and staying within the organization (Meyer \& Allen, 1997; Laschinger \& Wong, 1999).

Argyris (1998) states that employee empowerment is closely related to internal commitment and it is important that managers wishing to gain commitment of employees must empower the employees. This notion is supported by Conger and Kanungo (1988) who argue that delegating authority encourages commitment and enhances individual and organization commitment. Spreitzer, Kizilos, and Nason (1997) argue that employee empowerment has a relationship with job satisfaction and organizational commitment (Liden et al. 2001). This is in line with Boxall and Macky (2009) who posit that empowered employees are more committed to the organization. Similarly, Babakus, Yavas, Karatepe, and Ava (2003) point that in organizational behaviour empowerment is closely related to decentralization in decision making, increase latitude given to employees over their control of task eliciting affective reactions such as commitment.

Laschinger et al. (1999) in their survey of staff nurses in Mexico found that empowerment increased levels of trust which in turn had a positive influence on affective commitment. A similar study by Kehoe and Wright (2010) established that affective commitment partially mediates the relationship between human resource management practices and OCB. Kehoe and Wright (2010)'s findings indicated that affective commitment partially mediated the relationship between HRM and OCB. They proposed that empowerment promotes innovativeness, turning employees into a wellspring of novel ideas, through the relaxation of controls and sharing of power. Their study did not test the significance of the indirect effect. The authors drew attention to the limitations of the study suggesting that employee commitment is a mediator.

Seibert et al. (2011) established that there was a strong relation between internal motivation and commitment. They pointed that organizational commitment is elicited by psychological empowerment which brings a fit between work demands and the individual needs and values of an employee. The authors concluded that feelings of autonomy, competence, and impact are likely to increase the individual's commitment to the organization. Fernadez and Moldogazine (2011) posit that employee empowerment is positively related to job 
satisfaction, organization commitment and performance. Conversely, Ibua (2014) failed to establish a mediating effect of job related attitudes (job satisfaction and organizational commitment) on the relationship between empowerment and organizational performance. The said study used the research of Baron and Kenny (1986) to measure the mediating effect. Despite the wide use of this approach, recent studies such as Hayes (2007) have criticized the procedures of Baron and Kenny as it does not measure the indirect effect. Different from her study, Hayes (2007)'s process of mediation is applied in the study to measure for the mediating effect of organizational commitment.

Although these studies of Laschinger et al. (1999), Seibert et al. (2011) and Fernadez and Moldogazine (2011) suggest that notion that employee empowerment elicits commitment which in turn leads to organizational performance, there are very few studies that have explored this relationship to date. Moreover, results examining the mediating effect present mixed results. Drawing from this analysis, the study heeded their call by incorporating the intervening role of organizational commitment and the study proposes:

$\mathrm{H}_{2}$ : Organizational commitment mediates the relationship between empowerment and organizational performance.

\section{Employee Empowerment, Organization Citizenship Behavior and Organizational Performance}

OCB or extra-role (Katz, 1964) is a voluntary action or discretionary role that indirectly enhances cooperation within the organization. Paille, Grima, and Dufour (2012) cite the definition of Organ (1988) as the most common widely used definition of OCB. Organ (1988) defines OCB as individual behavior that is discretionary and not directly or explicitly recognized by formal reward system and that in aggregate it promotes effective functioning of the organization. Borman and Motowildo (1997) suggest that OCB is an energizing and active process in which employees enact discretionary effort that promotes effectiveness of an organization. Seibert et al. (2011) posit that OCB is an expression of identification and involvement in the entire workplace and not just one's defined work role. The definitions reveal that OCB is a matter of personal choice.

Tastan and Serikkan (2013) examined the relationship between psychological empowerment (personal development, self-determination, initiation, substantial impact and competency) and found a significant influence on voluntary behaviors among academic staff in universities in Istanbul. Drawing from social exchange theory, Tastan and Serikkan (2013) explain that empowerment can result in high quality exchange resulting in employees engaging in OCB. Organ (1998) observes that empowered employees feel obligated to honour their obligation by reciprocating in OCB. This argument is further supported by Kanter (1977)'s theory of psychological empowerment that employees who feel a sense of empowerment are likely to take active orientation beyond and above the call of duty. Thus, it can be argued that OCB moderates the relationship between employee empowerment and organizational performance.

$\mathrm{H}_{3}$ : Organizational Citizenship behaviour moderates the relationship between empowerment and organizational performance.

\section{Conceptual Framework}

The conceptual framework is drawn from theoretical underpinnings of social exchange theory knowledge gaps identified from empirical literature. In the schematic diagram, the direct influence of empowerment on firm performance forms the basis of the study $\left(\mathrm{H}_{1}\right)$. In line with theoretical and empirical literature, the study proposed that employee commitment mediates the relationship between empowerment and firm performance 
$\left(\mathrm{H}_{2}\right)$. On the other hand, OCB moderates the relationship between empowerment and firm performance $\left(\mathrm{H}_{3}\right)$. The interrelationship forming the bases of conceptual model is presented in Figure 1.

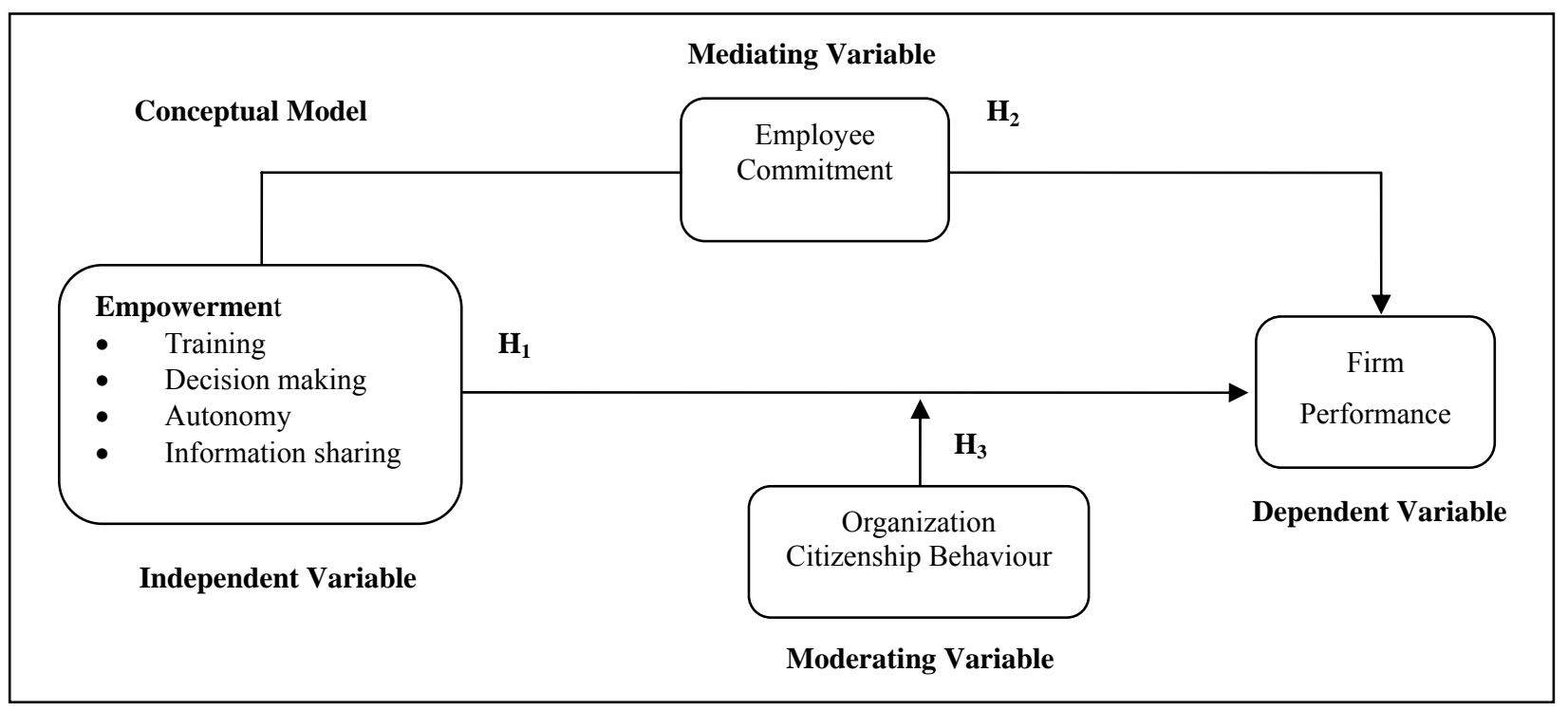

Figure 1. Conceptual framework.

\section{Research Methodology}

This study was a survey that targeted a manufacturing firm in Kenya. Out of the 96 questionnaires issued, 86 were returned, indicating a $91.6 \%$ response rate, leaving $8.4 \%$ unreturned. Data were collected at one point in time in the organization. 96 questionnaires were distributed randomly to selected employees representing around $13.2 \%$ of total population.

\section{Measures}

Dependent variable: Organizational performance was modeled as function of four dimensions of empowerment. Nine items were used to measure organizational performance. Subjective measures were used to measure organizational performance. Respondents were asked to indicate on a five-point Likert-type scale ranging from one to the extent to how they perceive 12-items of organizational performance.

Independent variable: Based on extensive review of literature, the survey instrument included items that assessed employee empowerment across a wide range of human resource management practices (20 items) were used to measure employee empowerment. The study adapted Bowen and Lawler's (1992; 1995) conceptualization of employee empowerment practices. Responses were rated on a five point-Likert type scale with anchors ranging from "one not all" to "five to a very large extent".

\section{Control Variables}

Recent reviews of literature (cf. Huselid 1996; Jackson \& Schuler, 1997) suggest that a variety of conditions in the external and internal organizational environment influence human resource management activities and firm performance, these conditions represent sources of potential extraneous variance. To reduce the possibility of spurious results caused by correlation among these variables and constructs of interest, the study included the following control measures in our statistical analysis. Biron and Bamberger (2010) propose gender and age, and personality type, experiencing can be included in such analyses. 


\section{Statistical Analysis}

In order to test the inter-correlations of the study variables, a correlation analysis was performed and the results are displayed in Table 1 . The correlation matrix also tests for possibility of multicollinearity among the study variables.

To test the study hypotheses several regression analyses were performed. Multiple regression analysis was performed to test the influence of employee empowerment on organizational performance. Hypothesis 1 proposed that employee empowerment is positively associated with organizational performance. A hierarchical multiple regression was used to perform the analysis. The control variable (gender) was entered in the first step and the second step involved entering dimensions of empowerment.

Hypothesis 2 proposed that employee commitment mediates the relationship between employee empowerment and organizational performance. Hayes (2007)'s process of testing mediation was performed and the results are presented in Table 3. Hypothesis 3 proposed that OCB has a moderating effect on the relationship between employee empowerment and organizational performance. Hayes (2007)'s process of testing moderation was used and results are presented in Table 4.

\section{Research Results}

The bivariate results indicate a significant relationship between the scales of employee empowerment, employee commitment, OCB, and organizational performance. Results in Table 1 show that the control variable (gender) has a significant and negative relationship with organizational performance $(r=0.310, p<$ $0.01)$. Empowerment has a significant relationship with employee commitment $(r=0.473, p<0.01)$. OCB has a significant relationship with empowerment $(r=0.355, p<0.01)$ and commitment $(r=0.674, p<0.01)$. Organizational performance had a significant relationship with scales of empowerment $(r=0.648, p<0.01)$, organizational commitment $(r=0.258, p<0.01)$ and no significant relationship with $\mathrm{OCB}(r=0.171, p<0.01)$.

Table 1

\section{Correlation Matrix}

\begin{tabular}{llllll}
\hline & 1 & 2 & 3 & 4 & 5 \\
\hline Gender & 1 & & & & \\
Empowerment & -0.172 & 1 & 1 & & \\
Commitment & -0.190 & $0.473^{* *}$ & $0.674^{* *}$ & 1 & \\
Citizenship behaviour & -0.012 & $0.355^{* *}$ & $0.258^{*}$ & 0.171 & 1 \\
Organizational performance & $-0.310^{* *}$ & $0.648^{* *}$ & 0.05 level $(2-t a i l e d)$.
\end{tabular}

Notes. ** Correlation is significant at the 0.01 level (2-tailed); * Correlation is significant at the 0.05 level (2-tailed).

Results on Table 2 show that gender accounted for 10.6 of the variance in organizational performance and the overall model and beta coefficient were negative but statistically significant $(\beta=-0.099, F=10.010, p<$ $0.05)$. The inclusion of decision making resulted in additional 40.0 percent of the variation being explained by employee empowerment $\left(R^{2}\right.$ change $\left.=0.400\right)$ showing a very substantive effect on organizational performance. The $F$ statistic and coefficient was significant $(F=16.408, p<0.05)$. Of the four dimensions of employee empowerment, information sharing $(\beta=0.348, p<0.05)$ and training $(\beta=0.323, p<0.05)$ had a positive and significant contribution to organizational performance, while autonomy $(\beta=0.187, p<0.05)$ and decision making $(\beta=0.030, p<0.05)$ had no contribution to organizational performance. 
Table 2

Regression Results for Empowerment and Firm Performance

\begin{tabular}{lllll}
\hline \multirow{2}{*}{ Variables } & \multicolumn{3}{c}{ Model 1 } & Model 2 \\
\cline { 2 - 5 } & $\beta$ & SE & $\beta$ & SE \\
\hline Constant & $0.564^{*}$ & 0.016 & $0.187^{*}$ & 0.051 \\
Gender & $-0.099^{*}$ & 0.031 & $-0.065^{*}$ & 0.025 \\
Autonomy & & & 0.187 & 0.110 \\
Decision making & & 0.030 & 0.060 \\
Training & & $0.323^{*}$ & 0.058 \\
Information sharing & & $0.348^{*}$ & 0.072 \\
$\mathrm{R}^{2}$ & 0.106 & & 0.506 & \\
Adjusted ${ }^{2}$ & 0.096 & & 0.475 & $16.408^{*}$ \\
$\mathrm{~F}$ & $10.010^{*}$ & & $0.4000^{*}$ & \\
$r^{2} \Delta$ & & & \\
\hline
\end{tabular}

Note. * Significant level at the 0.05 level.

Table 3

Testing for Mediation

\begin{tabular}{llll}
\hline Variables & Step 1 & Step 2 & Step 3 \\
\hline Constant & $0.196^{*}$ & 0.0918 & $0.1960^{*}$ \\
Gender & $-0.0661^{*}$ & -0.0324 & $-0.0679^{*}$ \\
Empowerment & $0.6753^{*}$ & $0.5979^{*}$ & $0.7077^{*}$ \\
Commitment & & & -0.0543 \\
$\mathrm{R}^{2}$ & 0.4654 & 0.2430 & 0.4684 \\
$F$ & $36.13^{*}$ & $13.216^{*}$ & $24.0826^{*}$ \\
\hline
\end{tabular}

Note. * Significant level at the 0.05 level.

The results of mediation in Table 3, show that step 1 of mediation model, the regression of empowerment on organizational performance was significant $(\beta=0.6753, p<0.05)$. Step 2 showed that the regression of empowerment on mediator (organizational commitment) was significant $(\beta=0.5979, p<0.05$ ). Step 3 of the mediation process shows that the mediator (organizational commitment) controlling for empowerment was not significant, $(\beta=-0.0543, p>0.05)$ but empowerment was a significant predictor of organizational performance $(\beta=-0.7077, p<0.05)$. Results on tests of indirect effect on mediation show the output at $95 \%$ confidence interval lies between -0.1396 LICI and 0.1051 ULCI with $95 \%$ interval. According to Hayes (2007) if zero (0) does not occur between LICI and ULCI, the study can conclude that indirect effect was significantly different from zero at $p<0.05$ and mediation or indirect effect of commitment was negative but significant.

Table 4 presents the results of moderation effect of OCB on the relationship between empowerment and performance. Moderation effect was tested using process developed by Hayes (2007) which does the centering and interaction terms automatically. The interaction term provides estimates of moderating effect. The results show that the centered values of OCB $(b=0.0244, p>0.05)$ did not significantly predict performance while employee empowerment significantly predicted performance $(b=0.6937, p<0.05)$ and the interaction term of empowerment $* O C B(b=0.6408, p>0.05)$ not statistically significant from zero, therefore, organization citizenship behavior is not a moderator. 
Table 4

Test for Moderation

\begin{tabular}{lllllll}
\hline Model & $b$ & $s e$ & $t$ & $p$ & LLCI & ULCI \\
\hline Constant & 0.5505 & 0.0138 & 39.8679 & 0.0000 & 0.5230 & 0.5779 \\
OCB & -0.0244 & 0.0807 & -0.3023 & 0.7632 & -0.1850 & 0.1362 \\
Empower & 0.6937 & 0.0912 & 7.6086 & 0.0000 & 0.5123 & 0.8751 \\
int_1 & 0.6408 & 0.4939 & 1.2975 & 0.1981 & -0.3419 & 1.6234 \\
GEND & 0.0651 & 0.0235 & -2.7644 & 0.0071 & -0.1119 & -0.0182 \\
$\mathrm{R}^{2}$ & 0.4773 & & & & & \\
$F$ & $22.3279 *$ & & & & & \\
\hline
\end{tabular}

Note. Level of confidence for all confidence intervals in output: 95.00 ; the following variables were mean centered prior to analysis; empowerment OCB; Interactions: int_1 empower X OCB.

\section{Discussion and Conclusion}

The results of this study indicated that employee empowerment had a positive significant influence on organizational performance. Overall, the results indicate that empowerment significantly predict firm performance providing support for Hypothesis 1. The results show that dimensions of training and information sharing were the most significant predictors of firm performance. Results were confirmed after controlling for gender. The findings of the study support findings by other researchers (Kariuki \& Murimi, 2015; Ibua, 2014; Conger \& Kanungo, 1990; Kazlauskaite et al., 2012). Similar to the study by Ibua (2014), that reported, 3.8 percent the current study shows that empowerment accounts for 10.6 percent of firm performance and 89.4 percent of firm performance could be accounted by factors such as employee commitment and OCB.

The study provides support that the weak model can be explained by organization commitment. This can be explained by the results of mediation that found that organizational commitment partially mediates the relationship between empowerment and organizational performance. Studies conducted by Laschinger et al. (1999), Fernandez and Moldogaziev (2011), and Meyer et al. (2000) established that employee empowerment is positively related to job satisfaction and organizational commitment. Meyer et al. (2000) found a strong correlation between affective commitment and outcome variables on turnover and withdrawal cognition, absenteeism job performance, OCB, stress and work-family conflict. The results further support the social exchange theory that empowered employees are willing to reciprocate with high levels of commitment given that they believe in their work and themselves. In addition, studies have found that commitment is positively related to behaviors that have a positive effect on organizational outcomes. Ibua (2014) failed to establish a mediating effect of job related attitudes (job satisfaction and organizational commitment) on the relationship between empowerment and organizational performance. This could be explained by use of Baron and Kenny (1986)'s study to measure the mediating effect which has found critics on lack of measuring the indirect effect.

The test of moderating effect of $\mathrm{OCB}$ on the relationship between empowerment and performance indicated that interaction term of $\mathrm{OCB}^{*}$ empowerment was not a significant predictor of performance. The results contradicting Tastan and Serikan (2013) explain that empowerment can result in high quality exchange resulting in employees engaging in OCB. Earlier study by Organ (1998) also indicated that empowered employees feel obligated to honour their obligation by reciprocating in OCB. Kanter (1977)'s theory of psychological empowerment that employees who feel a sense of empowerment is likely to take active orientation beyond the call of duty. Future studies should focus on managerial employees. The contradictory 
results could be explained by the fact that majority of employees were non-managerial who may not go beyond their call of duty to reach out to their colleagues.

\section{Limitations and Further Research}

Several limitations should be mentioned. First, all measures in the study were based on self-reports causing a concern of common method bias associated with self-reports. In the study utilized non-managerial employees which diminish the risks for common method bias. The test focused on only one organization. The study assumes that our findings might lend themselves to caution generalization to other sectors. The research was conducted on on only one organization and the sample size was small raising problems of generalizability. The information would not reflect the characteristics of other firms or industries at large. This is in conformity with the limitations and recommendations brought forward by Kazlauskaite et al. (2012) which included the aspect of data collection in more than one industry. It may be possible to conduct in-depth interviews and focus groups to complement information gathered from the questionnaire in the future. Despite the limitation, these studies highlight important findings and suggest direction for future research. More studies should be conducted on organizational commitment and OCB in different sectors of the economy.

\section{References}

Argyris, C. (1998). Empowerment: The emperor's new clothes. Harvard Business Review, 76(3), 98-105.

Babakus, E., Yavas, U., Karatepe, O., \& Ava, T. (2003). The effect of management commitment to service quality on employee affective and performance outcome. Journal of the Academy of Marketing Science, 31(3), 272-286.

Baron, R. M., \& Kenny, D. A. (1986). Moderator-Mediator variables distinction in social psychological research: Conceptual, strategic and statistical considerations. Journal of Personality and Social Psychology, 51(6), 1173-1182.

Biron, M., \& Bamberger, P. (2010). The impact of structural empowerment on individual well—Being and performance: Taking agent preferences, self-efficacy and operational constraints into account. Human Relations, 63(2), 163-191.

Blau, P. M. (1964). Exchange and power in social life. New York: John Wiley.

Boxall, P., \& Macky, K. (2009). Research and theory on high-performance work systems: Progressing and high involvement stream. Human Resource Journal, 11, 3-23.

Bowen, D. E., \& Lawler, E. E. (1992). The empowerment of service workers: What, why, how and when. Sloan Management Review, 31(3), 31-40.

Bowen, D. E., \& Lawler, E. E. (1995). Empowering service employees. Sloan Management Review, 36, 73-84.

Borman, W. C., \& Motowildo, S. J. (1997). Task performance and contextual performance: The meaning of personnel selection research. Human Performance, 10, 99-109.

Conger, J., \& Kanungo, R. (1988). The empowerment process: Integrating theory and practice. Academy of Management Review, 13(3), 471-482.

Cooper, C. L., \& Roberstson, I. (2004). International review of industrial organizational psychology. John and Wiley and Sons.

Fernandez, S., \& Moldogaziev, T. (2011). Empowering public sector employees to improve performance: Does it work? American Review of Public Administration, 41(1), 23-47.

Forrester, R. (2000). Empowerment: Rejuvenating a potential idea. The Academy of Management Review, 14(3), 67-80.

Guest, D. E. (1997). Human resource management and performance: A review and research agenda. International Journal of Human Resource Management, 8, 265-276.

Ibua, M. P. (2014). The influence of institutional factors and job-related attitudes in relationship between employee empowerment and performance of public universities in Kenya. $\mathrm{PhD}$ thesis, University of Nairobi.

Huselid, M. A. (1996). The impact of human resource management practices on turnover, productivity and corporate financial performance. Academy of Management Journal, 38, 635-672.

Jackson, S. E., \& Schuler, R. S. (1997). Technical and strategic human resource management effectiveness as determinants of firm performance. Academy of Management Journal, 40(1), 171-188.

Kanter, R. M. (1977). Men and women of the corporations. New York, NY: Basic Books. 
Kanter, R. M. (1986). The new managerial work. Harvard Business Review, 67, 85-92.

Kariuki, A., \& Murimi, C. (2015). Employee empowerment and organizational performance of Tata Chemical Magadi Ltd, Kenya. European Journal of Business and Management, 7(8), 190-200.

Katz, D. (1964). Motivational basis of organizational behavior. Behavioural Science, 9, 131-146.

Kazlauskaite, R., Buciuniene, I., \& Turauskas, L. (2012). Organizational psychological empowerment in the HRM-performance linkage. Employee Relations, 34(2), 148-158.

Kehoe, R. R., \& Wright, P. W. (2010). The impact of high performance human resource practices on employee attitudes and behaviors. Journal of Management, 366-391.

Lashley, C. (1995). Towards an understanding of employee empowerment in hospitality services. International Journal of Contemporary Hospitality, 7(1), 27-32.

Laschinger, H. K. S., \& Wong, D. (1999). Staff nurse empowerment and collective accountability: Effects on perceived accountability and self-rated work effectiveness. Nursing Economics, 17(6), 23-26.

Lawler, E. E. (1986). The high involvement management. San-Francisco: Jossey-Bass.

Liden, R. C., Wayne, S. J., \& Sparrow, R. T. (2001). An examination of the mediating role of psychological empowerment on the relation between job, interpersonal relationship and work outcomes. Journal of Applied Psychology, 85, 407-416.

Menon, S. T. (1995). Facets of subjective empowerment. Facet Analysis and Design, 129-140.

Menon, S. T. (2001). Employee empowerment: An integrative psychological approach.An International Review, 59, $153,180$.

Meyer, J., \& Allen, N. (1990). Affective commitment and continuance to the organization: Evaluation of concurrent and time-lagged relations: Journal of Applied Psychology, 75(60), 710-720.

Meyer, J., \& Allen, N. (1997). Commitment in the workplace. Thousand Oaks, CA: Sage.

Meyer, J., Stanley, D., Herscovitch, L., \& Topolnyski, L. (2002). Affective commitment and normative commitment to the organization. Journal of Vocational Behaviour, 61, 20-52.

Organ, D. W. (1988). Organizational citizenship behavior: The good soldier syndrome. Lexington: MA, Lexington Book.

Paille, P., Grima, F., \& Dufour, M. (2012). Contribution to social exchange in public organizations: Examining how support, trust, satisfaction and work outcomes are related. International Journal of Human Resource Management, 521-546.

Seibert, S. E., Silver, S. R., \& Randolph, W. A. (2011). Taking empowerment to the next level: A multiple-level model of empowerment, performance, and satisfaction. Academy of Management Journal, 47, 332-349.

Spreitzer, G. M. (1995). Psychological empowerment in the workplace: Construct definition, measurement, and validation. Academy of Management, 38, 1442-1465.

Spreitzer, G. M., Kizilos, M. A., \& Nason, S. W. (1997). A dimensional analysis of the relationship between psychological empowerment and effectiveness, satisfaction and strain. Journal of Management, 23(5), 679-704.

Spreitzer, G. M. (2007). Taking stock: A review of more than 20 years of research and empowerment at work. Centre for Effective Organization.

Tansky, J. W., \& Cohen, D. J. (2001). The relationship between organizational support, employee development and organizational commitment: An empirical study. Human Resource Development Quarterly, 12(3), 285-300.

Tastan, S. B., \& Serinkan, C. (2013). An empirical research on the relationship between individual psychological empowerment and voluntary performance behaviors: An assessment of combination of psychological power and intimate will. Journal of Global Strategic Management, 13, 95-120.

Thomas, K. W., \& Vetlhouse, B. A. (1990). Cognitive elements of empowerment: An interpretative model of intrinsic task motivation. Academy of Management Review, 15, 666-681.

Wood, R. H. (1999). Predicting is difficult especially about the future: Human resources in the new millennium. International Journal of Hospitality Management, 18, 443-456.

Yang, S., \& Choi, S. O. (2009). Employee empowerment and team performance. Team Performance Management, 15(5/6), 289-301. 